\section{7}

\section{2} 3

\title{
Amphibian Immunity—Stress, Disease, and Climate Change
}

\section{[for Special Issue on Neuroendocrine - Immune interaction (Brain and Immunity)]}

\author{
Louise A. Rollins-Smith ${ }^{\mathrm{a}, \mathrm{b}, \mathrm{c}^{*}}$
}

${ }^{a}$ Department of Pathology, Microbiology and Immunology, Vanderbilt University School of Medicine, Nashville, TN 37232, USA

${ }^{\mathrm{b}}$ Department of Biological Sciences, Vanderbilt University, Nashville, TN 37235, USA ${ }^{\mathrm{c}}$ Department of Pediatrics, Vanderbilt University School of Medicine, Nashville, TN 37232, USA

*Corresponding author. Mailing address: Department of Pathology, Microbiology and Immunology, A-5301 Medical Center North, Vanderbilt University School of Medicine, Nashville, TN 37232, USA. Telephone: +1 615343 4119. Fax: +1 615343 7392; E-mail: louise.rollins-smith@vanderbilt.edu

Abbreviations: ACTH, adrenocorticotropic hormone; AMP, antimicrobial peptide; CRF, corticotropin-releasing factor; HPI axis, hypothalamic-pituitary-interrenal axis; $B d$, Batrachochytrium dendrobatidis; Bsal, Batrachochytrium salamandrivorans; MALDI-TOF, matrix-assisted laser-desorption ionization time-of-flight 


\section{Abstract}

Like all other vertebrate groups, amphibian responses to the environment are mediated

Keywords: amphibian, Batrachochytrium, chytrid, corticosterone, HPI axis, ranavirus, stress,

\section{Introduction}

In view of recent world-wide declines of amphibian species due to fungal and viral infections, a review on the subject of the possible role of stress/neuroendocrine-immune system interactions in amphibian immune responses to these pathogens is needed. From a broad perspective, stress affecting amphibians comes in many forms including habitat destruction, overuse by humans, environmental chemicals, introduced species, climate change, and infectious diseases (Collins, 2010). For this article, I will limit my subject matter to natural stressors that 
47 may activate the HPI axis or the sympathetic nervous system and the effects of disease alone or

48 disease in the face of unpredictable climate changes. For a somewhat longer and broader review

49 of amphibian declines, disease, amphibian immunity, and stress in the context of the field of

50 "ecoimmunology", please see Rollins-Smith and Woodhams (2012). For more detailed reviews

51 of neural-immune system interactions with an evolutionary perspective, see Cohen and Kinney

52 (2007) and Kinney and Cohen (2009). For an excellent and updated overview of ranaviruses

53 and ranavirus diseases, see "Ranaviruses: Lethal Pathogens of Ectothermic Vertebrates (M.J.

54 Gray and V.G. Chinchar, eds., 2015). Throughout the text, I have indicated amphibian species by

55 their common names and their binomial (genus and species) names. These names conform to the

56 listings in AmphibiaWeb, the online amphibian information system developed and maintained by

57 the University of California, Berkeley.

\section{Ontogeny of Immunity in Amphibians}

Because amphibians undergo metamorphosis, the gradual development of immune

61 functions in tadpoles is interrupted during the metamorphic period. Lymphocyte-mediated

62 adaptive immune responses of tadpoles are characterized by having a limited B and T cell recognition repertoire resulting in poorer allorecognition and less diverse antibody responses

64 than adults (rev. in Rollins-Smith, 1998; Robert and Ohta, 2009). Following metamorphosis, 65 lymphocyte numbers expand rapidly and immune defenses mature. In the best-studied model 66 amphibian, the South African clawed frog Xenopus laevis, lymphocytes in the spleen at the end 67 of metamorphosis number about $1-2 \times 10^{5}$. By one to two months post-metamorphosis, the numbers have increased to about $10^{6}$, and they level off at about $10^{7}$ between six and 12 months 69 of age (Du Pasquier and Weiss, 1973; Rollins-Smith et al., 1984). Thus, for the rapidly 
developing $X$. laevis, an adult-type immune response capacity has developed within two months

71 of metamorphosis and expands during the first year of life. However, the early juvenile period is

72 a time of possible increased vulnerability to disease for most anurans (frogs and toads) because

73 the adaptive immune defenses are not yet mature.

Many amphibians also have well developed granular glands in the skin capable of

75 producing antimicrobial peptides (AMPs) (rev in Rollins-Smith and Conlon, 2005; Rollins-

76 Smith, 2009; König et al., 2015). AMPs are thought to be an important first line defense against

77 pathogenic bacteria, fungi, viruses, and other pathogens that would enter by way of the skin

78 (Rollins-Smith, 2009). The ontogeny of granular gland development has been studied in only a

79 few species. In northern leopard frogs [Rana (Lithobates) pipiens] and X. laevis, granular gland

80 development occurs in response to thyroid hormones and is complete at the end of metamorphic

81 climax (Bovbjerg, 1963; Heady and Kollros, 1964; Seki et al., 1989). A study of the synthesis of

82 mRNA for one AMP (brevinin-1SY) in developing wood frogs (Rana sylvatica) showed that

83 transcription was at very low levels until prometamorphic stages (Gosner 36-41) (Gosner, 1960)

84 and then increased significantly at subsequent stages through metamorphosis (Katzenback et al.,

85 2014). Juvenile $R$. pipiens have also been shown to have a full complement of AMPs at 3-6

86 months post-metamorphosis detected by matrix-assisted laser-desorption ionization time-of-

87 flight (MALDI-TOF) mass spectrometry (Pask et al., 2013). A study of five species sampled for

88 AMPs at metamorphosis [R. pipiens, Rana catesbeiana (Lithobates catesbeianus), Rana sierrae,

89 Litoria serrata, and Alytes obstetricans] showed that the repertoire of skin peptides expressed in

90 newly metamorphosed frogs (sampled within a few weeks after tail resorption) was the same as

91 that of more mature adults detected by MALDI-TOF mass spectrometry (Woodhams et al.,

92 2016). Thus, we hypothesized that newly metamorphosed juveniles of the southern leopard frog 
[Rana (Lithobates sphenocephalus) sphenocephala] would have a full complement of

antimicrobial peptides characteristic of adults as soon as they resorbed their tails. However, analysis of the induced skin peptides in metamorphs by MALDI-TOF mass spectrometry showed that the full complement and adult levels of AMPs were not present until 12 weeks after metamorphosis (Holden et al., 2015). Because the southern leopard frogs in this study were reared in outdoor mesocosms, it is possible that they were not developing under optimal conditions or metamorphosed rapidly because tank conditions were warming rapidly. This finding suggests that both innate AMP defenses and adaptive lymphocyte-mediated defenses may be compromised in young juveniles for several months after metamorphosis if growth conditions are not ideal, and thus, they may be more vulnerable to disease in this developmental period.

\section{The Brain-Stress Axis in Amphibians}

\subsection{The hypothalamo-pituitary-interrenal axis}

Amphibians share with other vertebrate groups a neuroendocrine stress axis (the hypothalamo-pituitary-interrenal axis, HPI) that mediates the response of the animal to its environment (Fig. 1). Neurosecretory neurons in the hypothalamus produce corticotrophinreleasing factor $(\mathrm{CRF})$ that stimulates cells of the pituitary gland to release corticotropin (homologous to adrenocorticotropic hormone, ACTH) (rev. in Dores and Lecaude, 2005). In amphibians, the interrenal glands serve the same function as the adrenal cortex in mammals and synthesize and release corticosteroid hormones (rev. in Denver, 2009). The main corticosteroid hormone released is corticosterone, and the main mineralocorticoid is aldosterone (Leboulenger et al., 1986; Feuilloley et al., 1990; Kloas and Hanke, 1990). The corticosteroid hormones have 
116 important roles in normal development, energy mobilization, and osmoregulation (rev in Denver,

117 2009). Although baseline levels of corticosteroids remain quite low through premetamorphic

118 and prometamorphic stages of development, the HPI axis is responsive to natural stressors or to

119 injection of ACTH (Glennemeier and Denver, 2002b). Thus, the HPI axis appears to be

120 responsive to stress even in young tadpoles. Several natural stressors have been shown to

121 increase corticosterone levels in larval amphibians in laboratory, mesocosm, and field settings.

122 These stressors that elevate corticosterone are food restriction (Crespi and Denver 2005; Crespi

123 and Warne 2013; Reeve et al., 2013), crowding (Glennemeier and Denver, 2002a), chronic

124 exposure to predation cues (Middlemis Maher et al., 2013), low pH (Chambers et al., 2013), and

125 pond drying (Denver, 1998, Crespi and Warne, 2013; rev. in Denver, 2013). Ranavirus infection

126 itself may be viewed as a stressor, as corticosterone levels were shown to increase within four

127 days of exposure of wood frog (R. sylvatica) tadpoles to ranaviruses (Warne et al., 2011). Within

128 a population of $R$. sylvatica tadpoles, there was heterogeneity in baseline corticosterone levels,

129 with those growing more slowly having higher corticosterone levels (Warne et al., 2013, Reeve

130 et al., 2013). Prior to metamorphosis, HPI activity increases and is important in stimulating

131 thyroid hormone secretion needed for morphological conversion from the aquatic tadpole form

132 and physiology to one adapted for terrestrial or semi-terrestrial life (rev. in Denver, 2013).

133 Interspersed within the interrenals and adjacent to steroidogenic tissues are also clusters

134 of chromaffin cells that synthesize catecholamines (epinephrine and norepinephrine). There are

135 few studies of the regulation of catecholamine release, but it is generally thought to be a central

136 component of the ACTH-induced stress response in amphibians (rev. in Perry and Capaldo,

137 2011). Stress, such as induced activity to escape a predator, was shown to elevate

138 catecholamines (Tufts et al., 1987; Withers et al., 1988; Hillman et al., 1998) and resulted in 
139 increased release of defensive skin peptides (Ramsey et al., 2010; Pask et al., 2012). The stress

140 of dehydration also resulted in the release of catecholamines in the marine toad (Bufo marinus,

141 now Rhinella marina) (Withers et al., 1988). Norepinephrine elevated glucose in bullfrogs $(R$.

142 catesbeiana) and the common frog (Rana temporaria), suggesting that this acute stress response

143 is important for rapid mobilization of energy reserves (Harri, 1981; MbangKollo and de Roos,

144 1983).

$145 \quad 3.2$ The sympathetic nervous system, catecholamines, and acute stress

146 There is a rich literature describing the role of the sympathetic nervous system on

147 immune system function in mammals (reviewed in Madden and Felten, 1995). Pioneering studies

148 of the connections of the sympathetic nervous system with the immune system of amphibians

149 were conducted in the 1990s. As reviewed by Cohen and Kinney (2007), the main features of

150 neural-immune system interactions shared by mammals and amphibians are as follows.

151 Lymphoid tissues are richly innervated and express receptors for neuropeptides,

152 neurotransmitters, and hormones (Felten et al., 1987; Kinney et al., 1994). When the receptors

153 are engaged, the functions of the immune cells are changed. When the sympathetic nervous

154 system is incapacitated by chemicals, lymphocytes become more easily activated in mammals

155 (reviewed in Madden and Felten, 1995) and in X. laevis (Kinney and Cohen, 2005). As shown in

156 mammals, cells of the immune system produce neuropeptides and hormones (Blalock, 2005;

157 Smith, 2003). Cytokines such as IL-1, IL-6, and TNF produced by immune cells are recognized

158 by receptors on cells of the nervous system (Maier, 2003). Thus, there is bi-directional

159 communication between the immune system and the nervous system of amphibians as well as

160 mammals. 
One component of the amphibian immune defense system that is especially sensitive to

catecholamines is the network of granular glands in skin (also called poison glands) of many amphibian species. The granular glands produce and store defensive peptides including antimicrobial peptides that inhibit $B d$ and ranaviruses (reviewed in Rollins-Smith and Conlon, 2005; Rollins-Smith 2009; and Rollins-Smith et al., 2011), and they are innervated by sympathetic nerves (Sjoberg and Flock, 1976). Following alarm or injury, the sympathetic nervous system is activated, adrenergic receptors are stimulated (Benson and Hadley, 1969; Holmes and Balls, 1978), and the contents of the glands are released to the surface of the skin. Even a mild simulated "alarm stress" due to forced activity for 5 to 10 minutes induces release of significant amounts of defensive peptides in X. laevis and $R$. pipiens (Ramsey et al., 2010; Pask et al., 2012). Thus, acute and temporary stress that activates release of catecholamines would be protective against skin pathogens introduced by an injury.

\section{Corticosteroids and the Immune System in Amphibians}

Amphibian lymphocytes are very sensitive to the effects of corticosteroids. In previous studies, supraphysiological concentrations of corticosteroids inhibited antibody responses and reduced thymus size and numbers of circulating lymphocytes in adult frogs (Garrido et al., 1987, Plytycz et al., 1993). Tumor allograft rejection was impaired (Rollins and McKinnell, 1980), and the immune response to Mycobacterium marinum was reduced in leopard frogs (Ramakrishnan et al., 1997). Other studies suggested that elevated corticosteroids change the pattern of lymphocytes, neutrophils, and eosinophils detected in circulating blood (Falso et al., 2015; de Assis et al., 2015; Kaiser et al., 2015). A frequent observation is that the ratio of neutrophils to lymphocytes changes when amphibians are stressed and corticosteroids are involved (Peterson et al. 2010; Narayan and Hero, 2011; Falso et al., 2015; de Assis et al. 2015). 
184 This pattern is not replicated in other studies (Kaiser, et al., 2015). It has been suggested that 185 simply monitoring leukocyte changes is an adequate measure of physiological stress in 186 amphibians (Davis et al., 2008). However, given the complexity of leukocyte movements into 187 and out of the blood and tissues, assessing stress using leukocyte counts alone without 188 monitoring corticosteroids is a highly imperfect measure. In vitro, proliferation of frog lymphocytes in response to the classical T cell mitogen, phytohemagglutinin (PHA), was inhibited, and viability of both thymocytes and splenocytes was

191 reduced by physiologically relevant concentrations $(1-10 \mathrm{ng} / \mathrm{ml}=3-30 \mathrm{nM})$ of corticosterone 192 (Rollins-Smith \& Blair, 1993). Both corticosterone and aldosterone at concentrations of 1-10 nM 193 inhibited lymphocyte proliferation and induced apoptosis of lymphocytes from tadpoles or adults 194 (Rollins-Smith et al., 1997). The loss of lymphocytes in vitro and in tadpoles at metamorphosis 195 was reversed by the corticosteroid receptor antagonist RU486 (Rollins-Smith et al., 1997; Barker 196 et al., 1997).Thus, physiologically relevant increases in corticosteroids alter lymphocyte activity 197 in vitro and in vivo.

\section{Amphibian Declines Due to Disease}

In recent years, three emerging pathogens have been linked to global amphibian declines.

201 They are ranaviruses and two species of chytrid fungi in the genus Batrachochytrium.

203 salamanders and frogs, as well as fish and reptiles. They target a number of cell types (e.g., 204 liver, kidney, interrenal gland) in susceptible animals causing necrosis and hemorrhaging (rev. in 205 Gray et al., 2009; Miller et al., 2011). Symptoms include lethargy, anorexia, and buoyancy 206 problems. Death occurs due to tissue death in multiple organs (Gray et al., 2009). Outbreaks of 
ranavirus disease in which entire populations of larvae succumb to disease have occurred in North America, South America, Australia, Asia, and Europe. Thus, ranaviruses present serious risks for many amphibian populations around the world (rev. in Miller et al., 2011).

210 Susceptibility varies by species. Among North American species, those with a short larval 211 period, limited species range, or semi-permanent breeding sites are more susceptible than slowly 212 developing and more widespread species (Hoverman et al., 2011). Ranavirus infections appear 213 to cause mortality at larval stages while adults are more resistant and are known to carry 214 infections that are asymptomatic (De Jusús Andino et al., 2012; Robert et al., 2014; Crespi et al., 215 2015; rev in Brunner et al., 2015). In wood frogs, the greatest vulnerability appears to be in the 216 late (prometamorphic) larval stages (Warne et al., 2011). Batrachochytrium dendrobatidis $(B d)$ is a chytrid fungus that infects amphibian skin 218 causing the disease chytridiomycosis (Berger et al., 1998; Longcore et al., 1999; rev. in Rollins219 Smith et al., 2011). It is linked to ongoing global declines and extinctions of amphibians (Stuart 220 et al., 2004; Skerratt et al., 2007; rev. in Fisher et al., 2012). The infection is confined to the 221 skin, and degeneration of the skin results in an imbalance in essential ions and eventual death 222 due to cardiac arrest (Voyles et al., 2009; 2012b). Both anuran amphibians (frogs and toads) 223 (Berger et al., 1998) and caudate (tailed) amphibians may succumb to chytridiomycosis caused 224 by $B d$ (Thien et al., 2001; Bovero et al., 2008; Raffel et al., 2015); however it seems to be of 225 lower virulence in many salamander species (Chatfield, et al., 2012; Pasmans et al., 2013; 226 Muletz, et al., 2014; Bales, et al., 2015). More recently, a second species in the genus 227 Batrachochytrium was discovered. This new pathogen, Batrachochytrium salamandrivorans 228 (Bsal), appears to have originated in Asia and is highly pathogenic to salamanders but appears to 
229 spare their frog and toad cousins (Martel et al., 2013; 2014). Both emerging fungal pathogens

230 threaten many amphibian species globally.

232 6. Does stress impair immunity and increase disease susceptibility in larval amphibians?

2336.1 Stress, corticosteroids, and ranavirus disease in tadpoles and recently metamorphosed 234 juveniles

Given that ranavirus infections primarily cause mortality during the larval stage, studies 236 that were designed to investigate the effects of environmental stress on disease susceptibility 237 have focused on the this life history stage. In northern leopard frogs ( $R$. pipiens), ranaviruses 238 have been associated with a number of mortality events in larval and metamorphosing frogs 239 (Greer et al., 2005; Hoverman et al., 2011). Crowding of premetamorphic leopard frog tadpoles 240 (Gosner stage 25) is a natural stressor that resulted in the elevation of whole body corticosteroids 241 to a level of approximately 0.15 to $0.2 \mathrm{ng} / \mathrm{g}$ (Glennemeier and Denver, 2002a). Under roughly 242 comparable conditions of crowding, exposure of premetamorphic tadpoles to ranaviruses 243 resulted in decreased growth of tadpoles, increased mortality, and a more rapid rate of death in 244 comparison with tadpoles infected and reared at somewhat lower densities (Echaubard et al., 245 2010). These observations suggest that crowding stress may have induced modest increases in 246 corticosteroids and directed energy away from rapid growth and immune function and towards 247 maintenance physiology. Because there were no measures of immune function or corticosterone 248 levels in this virus-infection study (Echaubard et al., 2010), it is unclear whether immune 249 defenses were impaired leading to increased disease. In another study of the effects of natural stressors on premetamorphic wood frog

251 tadpoles, Reeve et al., (2013) exposed Gosner stage 25 tadpoles to high-density, predator-cues, 
252 or low-food conditions. After 14 days, the tadpoles were exposed to ranavirus (either by adding

253 virus directly to water or by exposing the tadpoles to infected tadpoles introduced to the tank).

254 Low food conditions significantly increased corticosteroids to a level of about $0.5 \mathrm{ng} / \mathrm{g}$ (and

255 many tadpoles died), whereas high density and predator cues in this experiment did not lead to

256 increased corticosterone (Reeve et al., 2013). This study also showed that exposure to

257 ranaviruses did not increase mortality or time to death beyond that of control tadpoles in any of

258 the treatments. Although corticosterone was elevated to an average of less than $1 \mathrm{ng} / \mathrm{g}$ in the

259 low-food group, this concentration would be in the range of concentrations sufficient to inhibit

260 amphibian lymphocytes (1 ng/ml) (Rollins-Smith and Blair, 1993). Thus in this study, low-food

261 stressed tadpoles or predator-stressed tadpoles may have experienced physiological or behavioral

262 changes, but there was no higher rate of mortality than controls. The findings from this study

263 question whether natural environmental stressors affect susceptibility to ranavirus infections in

264 wood frogs, but the dose of ranavirus may have been too high to see differences.

265

266

6.2 Stress, corticosteroids and chytridiomycosis in tadpoles and recently metamorphosed

267 juveniles

Batrachochytrium dendrobatidis $(B d)$ is generally not lethal to tadpoles because it infects

269 only the keratin-bearing cells of the mouth parts (Berger et al., 1998). Few studies have

270 examined the possible role of the HPI axis in the setting of disease caused by Batrachochytrium

271 fungi in tadpoles. Nutritional status of southern leopard frog tadpoles (R. sphenocephala)

272 appeared to play a role in their capacity to resist $B d$ infection. Tadpoles raised on a low-protein

273 diet had impaired immune defenses and were less resistant to infection in the mouth parts. The

274 interpretation of these experiments was that tadpoles raised on a protein-rich diet had more 
275 effective immune capacity which might have aided in resistance to infection or clearance of $B d$

276 from the mouth region after infection (Venesky et al., 2012). Although corticosteroid hormones

277 were not assessed in this study, it is possible that poor nutrition resulted in elevated

278 corticosterone as shown in wood frog larvae (Reeve et al., 2013) and may have inhibited

279 development of immune capacity in these leopard frogs.

280 Although the mechanism of pathogenesis is not known, there are number of studies that 281 suggest deleterious effects of $B d$ on development and survival of tadpoles and metamorphosing

282 adults. Laboratory exposure of developing toad tadpoles [Anaxyrus (Bufo) fowleri, Bufo bufo) to $283 B d$ zoospores resulted in decreased mass at metamorphosis (Parris and Cornelius, 2004; Garner 284 et al., 2009) and increased mortality after metamorphosis (Garner et al., 2009). One potential 285 mechanism to explain reduced size is the effects of infection in the mouth on the ability to forage 286 for food and consume food. In a study of Fowler's toads (A. fowleri), Bd-infected tadpoles spent 287 less time foraging than uninfected or unexposed tadpoles and had less food in their digestive 288 tracts (Venesky et al., 2009). If these $B d$-infected tadpoles were nutritionally compromised, they 289 might have had increased corticosteroids (not measured in this study) and decreased capacity to 290 resist or clear infections in the mouth parts.

7. Does disease alone alter the stress axis in tadpoles and metamorphosed juveniles?

\subsection{Ranaviruses as agents of stress}

An alternative interpretation of studies that show deleterious effects of ranaviruses or $B d$ 295 on tadpole development is that the pathogen, itself, is a "stressor" that results in increased 296 chronic release of corticosteroids. Exposure of wood frogs at prometamorphic stages (Gosner 297 37-39) to a local New York isolate of ranaviruses resulted in some early mortality, modestly 
298 increased whole body levels of corticosterone (approximately $2 \mathrm{ng} / \mathrm{g}$ ), and decreased mass in 299 comparison with unexposed control tadpoles (Warne et al., 2011). This suggests that viral 300 exposure itself induced a stress response greater than the normally elevated levels of 301 corticosterone expected of tadpoles nearing metamorphosis (rev. in Denver, 2013). Disease302 induced stress in late tadpole stages has the potential to accelerate metamorphosis (Warne et al., 303 2011; Reeve et al., 2013). This could be considered to be adaptive (allowing individuals to 304 escape the pond to reduce exposure) or maladaptive (leading to death because of the excessive 305 use of reserve energy resources or further reduction of immune capacity as the frogs emerge 306 from metamorphosis).

A separate study of the effects of food-deprivation and reduced water volume during later 308 stages of larval development in wood frogs (R. sylvatica) showed that the low-food and low309 water treatment groups of tadpoles had elevated corticosterone and reduced mass and body 310 condition as they neared metamorphosis (Crespi and Warne 2013). After metamorphosis, these 311 "stressed" froglets were unable to catch up in terms of growth and fat storage. Although disease 312 was not a part of this study, it is reasonable to hypothesize that these froglets that were stressed 313 at the larval stage might be more susceptible to infections as postmetamorphic juveniles. The 314 Crespi and Warne (2013) study also showed that the "doubled stressed" tadpoles had a blunted 315 response to handling stress at 10 weeks after metamorphosis (reduced corticosterone). A further 316 study of size variability in developing wood frogs showed that the smallest tadpoles leaving the 317 pond last also had a reduced corticosteroid stress responses to mechanical stress at 10 weeks 318 after metamorphosis (Warne and Crespi, 2015). This may also suggest a blunted corticosteroid 319 response that could be adaptive to enable these small frogs to preserve immune capacity or the 320 capacity to mobilize energy reserves if they are hit with a disease pathogen. 
One of the first innate immune responses to frog virus 3 (FV3, a well-characterized

322

323

324

325

326

327

328

329

330

331

332

333

334

335

amphibian ranavirus) in adult frogs (X. laevis) is the production of tumor necrosis factor alpha (TNF- $\alpha$ ) and interleukin-1 beta (IL-1 $\beta$ ) (Morales et al., 2010) that would be expected to activate the HPI axis (rev. in Dunn, 2006). This response is muted in tadpoles (De Jesús Andino et al., 2012), and tadpoles are much more susceptible to ranavirus-induced pathogenesis and death (Gantress et al., 2003; rev. in Grayfer et al. 2012). Tadpoles, however, have a higher basal level of mRNA for TNF- $\alpha$ and IL-1 $\beta$, and tissue damage from the viral infection may exacerbate elevated inflammatory responses resulting in mortality rather than clearance (rev. in Grayfer et $a l .$, 2012). In adult frogs, the activation of the HPI axis would be expected to result in increased corticosteroids that could modulate the immune response (rev. in Webster and Sternberg, 2004). In prometamorphic tadpoles, the HPI axis may be "ramping up" to promote metamorphic changes, and an added infection and resulting elevated corticosteroids may reduce immune functions. In turn, this may limit the capacity of late-stage tadpoles to control a viral infection.

\subsection{Batrachochytrium as an agent of stress}

Several recent studies have evaluated the effects of natural infections by $B d$ on glucocorticoid release by individual tadpoles (Gabor et al., 2013; 2015). Natural populations of larval midwife toads (Aletes obstetricans and Aletes muletensis) infected or not with $B d$ were examined for corticosterone release in the water. Infected populations of both species had higher rates of corticosterone release than uninfected populations (Gabor et al., 2013). In nature, higher elevation populations of $A$. obstetricans were infected with $B d$ and shed more corticosterone than lower elevation populations. In a laboratory experiment, A. muletensis tadpoles were exposed repeatedly to a highly virulent global panzootic lineage isolate ( $B d$ GPL) or a less virulent isolate 
344 (Bd CAPE) or no pathogens for 46 days, and then corticosterone was measured. The $B d$ GPL exposed tadpoles shed more corticosterone. This suggests that more severe disease results in a greater stress response.

In nature, $B d$ infected metamorphosed froglets of A. obstetricans in the final stages of chytridiomycosis (unable to right themselves) shed more corticosterone than healthier froglets that were able to right themselves (Gabor et al., 2015). These studies strongly suggest that $B d$ infection of tadpoles and metamorphosed juveniles is physiologically stressful and the stress response may be maladaptive.

\section{Does stress impair immunity and increase disease susceptibility in adult amphibians?}

\subsection{Stress, corticosteroids, and ranavirus disease in adult amphibians}

Adult frogs naturally experience elevated corticosteroids during periods of explosive breeding when heightened activity is required to call and mate, and frogs may be fasting (Harvey et al., 1997; Orchinik et al., 1988). In a recently published study, the health and disease status of populations of adult wood frogs ( $R$. sylvatica) returning to spring breeding ponds provided a good measure of possible environmental stressors and their relationship to circulating corticosteroids and sex hormones (Crespi et al., 2015). Prevalence of $B d$ and ranavirus in these male frogs showed no correlation with potentially immunosuppressive corticosterone. Although only a small fraction of the frogs carried $B d(2 \%)$, about $39 \%$ of frogs tested positive for the presence of ranaviruses. There were no outbreaks of ranavirus disease in adults, but males returning to ponds with poor body condition were the most likely to be infected. Previous studies of X. laevis adults infected with FV3 showed that apparently healthy adult frogs carried quiescent or latent infections in macrophage populations (Robert et al., 2007; Morales et al., 
367 2010; reviewed in Grayfer et al., 2012). Thus, a combination of marginal health status and latent

368 virus infections may contribute to a few sick individuals that spread ranaviruses to other

369 previously uninfected adults who come to the breeding sites.

370 An important question to ask is whether temporary natural stressors such as increased

371 activity for breeding or long-distance migration might elevate corticosteroids and alter immune

372 responses. One recent study radio-tracked cane toads [Rhinella (Bufo) marina] migrating during

373 rainy nights in Australia (Brown and Shine, 2014). After application of radio transmitters and

374 tracking for seven days, blood corticosterone was measured immediately at capture and again

375 after 24 hours of confinement stress. Several immune parameters were measured at the same

376 time. Corticosterone levels were somewhat elevated (6 ng/ml), and they increased with

377 confinement stress (18 ng/ml) (Brown and Shine, 2014). These concentrations are comparable to

378 levels measured in amplexing toads (Orchinik et al., 1988). Bacterial killing activity and

379 phagocytic activity were reduced in toads that had traveled the greatest distance, but

380 corticosterone levels were no greater than controls that had also been radio-tracked but traveled a

381 shorter distance. A previous study by the same group showed that confinement stress increased

382 corticosterone levels in cane toads and decreased bacterial killing activity (Graham et al., 2012).

383 Another study of a different toad species [cururu toads (Rhinella icterica)] by this group also

384 showed that severe confinement stress reduced bacterial killing activity. At the same time they

385 noted an increased neutrophil/lymphocyte ratio (de Assis et al., 2015). This suggests that the

386 temporary natural stress of movement or confinement may affect complement-mediated bacterial

387 killing while increasing neutrophil activity. It is unclear from studies of this type whether, the

388 apparent increase in neutrophils is due to greater release of neutrophils from hematopoietic

389 tissues or results from a decrease in lymphocyte numbers in the blood. In contrast to bacterial 
killing activity, PHA-induced swelling (due to the likely infiltration of macrophages and

391 lymphocytes by 48 hours) was enhanced in the furthest migrating marine toads (Brown and

392 Shine, 2014). Thus, these somewhat stressed toads were quite competent to mount a delayed-

393 type hypersensitivity (DTH) response to PHA. Although natural stressors such as breeding

394 activity or long-distance travel on rainy nights have not been conclusively linked to greater

395 susceptibility to ranaviruses, it is possible that reduced phagocytic activity could allow for a less

396 robust response to ranaviruses. In X. laevis, macrophages are key defenders of adults from

397 experimental ranavirus infections (Morales, et al., 2010; De Jesus Andino, et al., 2012; Grayfer

398 and Robert 2015).

399

400

\subsection{Stress, corticosteroids, and chytridiomycosis in adult amphibians}

401

Unlike ranavirus disease, which is a systemic infection affecting multiple organs, $B d$

402 infections are confined to the skin (Berger et al.,1998; Longcore et al.,1999; Pessier et al.,1999;

403 Berger et al., 2005). Thus, if stress is able to elevate corticosteroids and affect the macrophage

404 and lymphocyte populations in the skin, then affected amphibians might be more susceptible to

405 repeated rounds of infection and reinfection within the skin compartment. The link between

406 stress, corticosteroids, and $B d$ is not well-established. The question remains whether

407 environmental stressors can alter the HPI axis and allow for infection or whether infection with

$408 B d$ itself is a severe stress that elevates corticosteroids. As mentioned above, metamorphs of $A$.

409 obstetricans dying with $B d$ infections (unable to right themselves) had higher levels of

410 corticosterone release in urine than more healthy individuals that could right themselves (Gabor

411 et al., 2015). Similarly, male Stony Creek frogs (Litoria wilcoxii) identified as positive for Bd

412 infection had slightly higher baseline urinary corticosterone concentrations in comparison to $B d$ 
413 negative male frogs (Kinderman et al., 2012). A similar result was observed in Australian green

414 tree frogs (Litoria caerulea) experiencing chytridiomycosis. Diseased frogs had elevated levels

415 of corticosterone, decreased plasma sodium and potassium, fewer circulating lymphocytes, and

416 elevated numbers of neutrophils in the blood (Peterson et al., 2013). Thus, elevated

417 corticosteroid hormones may be an attempt by infected frogs to return to physiological

418 homeostasis, but the response may instead exacerbate the disease.

\section{How might climate change alter the stress axis and disease outcomes in amphibians?}

At present, many groups are in the process of trying to predict how future climate change

422 may impact survival of ectothermic animals such as amphibians. According to the most recent

423 report of the Intergovernmental Panel on Climate Change (IPCC) (Pachauri et al., 2014),

424 temperatures will likely continue to increase resulting in extreme heat waves and extreme rain

425 events. Changes in rainfall will not be uniform, increasing at high latitudes and mid-latitude wet

426 regions but decreasing in many mid-latitude and subtropical regions. However, climate change

427 is also expected to affect the variability of temperature and precipitation, and host-pathogen

428 interactions may be complex under future climate scenarios (Schär et al., 2004, Pounds et al.,

429 2006, Yeh et al., 2009). For example, longer and colder winters in the USA due to the

430 "Greenland block" effect (Gramling 2015) could stress adults, delay breeding, and shorten the

431 period for larval development such that newly metamorphosed amphibians would have less

432 effective immune defenses including fewer lymphocytes in thymus and spleen (Rollins-Smith et

433 al., 1988) and delayed expression of AMPs in the skin (Holden et al., 2015). An increase in

434 temperature variation may also impair amphibian defenses and increase the risk of $B d$ epidemics

435 (Rohr and Raffel 2010, Raffel et al., 2013). 
The diverse and extensive literature describing the effects of cold on immune functions in

437

438

amphibians spans more than four decades and was recently reviewed (Rollins-Smith and Woodhams, 2012). Many of the previous studies describe the effects of natural hibernation in cold-adapted species such as northern leopard frogs, $R$. pipiens, or the European common frog (R. temporaria). In general, immune system functions are dramatically reduced during hibernation. Such changes may fall into the category of immune system accommodations or trade-offs. It is energetically costly to produce lymphocytes in winter when metabolism is reduced. The potential limitation of this biological strategy is that there is often a lag of weeks before the immune system recovers full capacity in the spring.

In addition to changes in immune function due to hibernation, immune responses in amphibians also change due to temporary fluctuations in temperature. The antibody response of the marine toad (B. marinus, now R. marina) was delayed and reduced when the toads were kept at $15^{\circ} \mathrm{C}$ rather than $25^{\circ} \mathrm{C}$. Toads immunized at $25^{\circ} \mathrm{C}$ and transferred to $15^{\circ} \mathrm{C}$ also showed a delayed switch to low molecular weight antibodies (Lin and Rowlands, 1973). Marine toads kept at $20^{\circ} \mathrm{C}$ had significantly reduced antibody titers against horse red blood cells in comparison with toads at $37^{\circ} \mathrm{C}$ (Cone and Marchalonis, 1972). Another classic measure of $\mathrm{T}$ cell function in amphibians, skin allograft rejection is also strongly affected by temperature. Skin allograft rejection in the eastern newt, $N$. viridescens, showed no differences in the kinetics of rejection at $23^{\circ} \mathrm{C}$ or $30^{\circ} \mathrm{C}$. However, at $20^{\circ} \mathrm{C}$ rejection was delayed, and at $10-15^{\circ} \mathrm{C}$, no rejection occurred. When cold newts were transferred to warmer temperatures, rejection occurred within 36 days (Cohen, 1966). In adults of other species [Rana esculenta (now considered to be Pelophylax lessonae and Pelophylax redibundus); Bombina bombina; and, B. bufo), there was a noticeable delay in the timing of skin allograft rejection at $10^{\circ} \mathrm{C}$ in comparison with $22^{\circ} \mathrm{C}$ (Jozkowicz and 
459 Plytycz, 1998). In X. laevis, even a small $\left(3^{\circ} \mathrm{C}\right)$ difference in temperature significantly delayed rejection by young postmetamorphic frogs. At $24^{\circ} \mathrm{C}$, rejection occurred within 15 days, but was delayed to about $18-19$ days at $21^{\circ} \mathrm{C}$ (DiMarzo, 1980; rev. in Cohen et al., 1985). Thus, both B

462 cell and $\mathrm{T}$ cell responses are impaired when temperatures are reduced from the optimal 463 temperature for the host.

Since amphibian immune defenses are impaired in the cold, it might be expected that

465

466

467

468

469

470

471

472

473

474

475

476

477

478

479

480

481

some disease outbreaks would be associated with colder temperatures. Chytridiomycosis has been associated with high elevation and cooler temperatures in multiple studies (Bradley et al., 2002; Berger et al, 2004; Drew et al., 2006; McDonald et al., 2005; Kriger et al., 2007; Savage et al., 2011; Olson et al., 2013; rev. in Fisher et al., 2009; rev. in Rollins-Smith and Woodhams 2012). Furthermore, B. dendrobatidis thrives at cool temperatures (zoospores have longer period of activity) (Woodhams et al., 2008; Voyles et al., 2012a). Thus, prevalence of infection can increase in cooler seasons (Woodhams and Alford, 2005; McDonald et al., 2005).

The effects of temperature on development of ranavirus disease seem to be more complex. Colder temperatures appeared to affect the probability of infection and mortality of leopard frog (R. pipiens) and wood frog (R. sylvatica) tadpoles exposed to ranaviruses in a controlled laboratory study. A temperature of $14^{\circ} \mathrm{C}$ significantly increased the infection rate and mortality in comparison with $22^{\circ} \mathrm{C}$ (Echaubard et al. 2014). In contrast, exposure of European common frog (R. temporaria) tadpoles to frog virus 3 (FV3), at 15 or $20^{\circ} \mathrm{C}$ showed that mortality was greater at $20^{\circ} \mathrm{C}$ (Bayley et al., 2013). In field studies, greater prevalence of ranavirus infected tadpoles or larval salamanders were sometimes linked with winter temperatures (Gray et al., 2007; Rojas et al., 2005) and sometimes linked with warmer fall temperatures (Hoverman et al., 2012). These conflicting results suggest that the interactions of 
482 amphibian hosts with ranaviral pathogens are complex. Cool temperatures may impair

483 immunity, but viruses can replicate more rapidly and may be shed at higher rates under warmer 484 conditions.

485 A growing body of evidence suggests that warming temperatures strongly affect 486 amphibian interactions with Batrachochytrium pathogens. In culture, $B d$ and $B s a l$ are killed at 487 temperatures above $28^{\circ} \mathrm{C}$ for $B d$ and $25^{\circ} \mathrm{C}$ for $B$ sal (Piotrowski et al., 2004, Woodhams et al., 488 2008, Martel et al., 2013), and survival of exposed amphibians is often greater at warmer 489 temperatures (Berger et al., 2004, Andre et al., 2008, Bustamante et al., 2010). These studies 490 suggest that an increase in mean temperature, as is predicted with global climate change, might 491 be favorable to amphibians exposed to Batrachochytrium species, decreasing the likelihood of 492 outbreaks and declines due to chytridiomycosis. However, warming temperatures in cooler 493 regions may also allow for greater chytrid propagation and greater ranavirus shedding, increasing 494 the possibility of infection and mortality.

495

\section{Concluding Remarks}

The immune system of amphibians is exquisitely tuned to respond to pathogen

498 challenges, and the HPA/I axis acts as a brake to prevent collateral damage to host tissues.

499 Natural stressors (nutritional deficits, crowding, predators, breeding activity etc.) can elevate 500 corticosteroid levels, but they do not necessarily predispose healthy well-nourished hosts to 501 greater disease vulnerability. Metamorphosing tadpoles and recently metamorphosed juveniles

502 may be an exception (more vulnerable to disease) because the immune system is rapidly being

503 reorganized and innate skin defenses may be diminished if the tadpoles were nutritionally

504 stressed. Ranaviruses or Batrachochytrium pathogens alone are significant causes of 
505 physiological stress and in severe disease when disease symptoms emerge, elevated

506 corticosteroids may impair immune defenses and exacerbate the disease state. Prolonged stress,

507 whether from disease or from environmental causes, may drain immune capacity. Climate

508 change may benefit some amphibian species that can adapt to warm temperatures that kill

509 Batrachochytrium pathogens or increase defenses against ranaviruses. On the other hand,

510 warmer temperatures that are still below the lethal limits for Batrachochytrium species may also

511 increase the presence of infectious zoospores or ranaviruses. Some species may be unable to

512 find suitable habitats and may experience more events of acute and prolonged stress that will

513 likely impair their immune defenses. Thus, the future for many amphibian species remains in

514 doubt.

515

516 11. Acknowledgements

517 Work from the Rollins-Smith laboratory was supported by National Science Foundation grants

518 IOS-0843207 and IOS-1121758 (to L.R-S). I thank Erica J. Crespi, University of Washington,

519 and two anonymous reviewers for thoughtful comments and discussion in preparation of this

520 manuscript.

521

522 12. References

523 1. Andre, S.E., Parker, J. and Briggs, C.J. 2008. Effect of temperature on host response

524 in Batrachochytrium dendrobatidis infection in the mountain yellow-legged frog

525 (Rana muscosa). J. Wildl. Dis. 44, 716-720.

526 2. Bales, E.K., Hyman, O.J., Loudon, A.H., Harris, R.N., Lipps, G., Chapman, E.,

527 Roblee, K., Kleopfer, J.D., and Terrell, K.A. 2015. Pathogenic chytrid fungus 
Batrachochytrium dendrobatidis, but not B. salamandrivorans, detected on eastern hellbenders. PLoS One. 10(2):e0116405.

3. Barker, K.S., Davis, A.T., and Rollins-Smith, L.A. 1997. In vitro studies of spontaneous and corticosteroid-induced apoptosis of lymphocyte populations from metamorphosing frogs/RU486 inhibition. Brain Behav. Immun. 11, 119-131.

4. Bayley, A.E., Hill, B.J., and Feist, S.W. 2013. Susceptibility of the European common frog Rana temporaria to a panel of ranavirus isolated from fish and amphibian hosts. Dis. Aquat. Organ. 103, 171-183.

5. Benson, B.J. and Hadley, M.E. 1969. In vitro characterization of adrenergic receptors controlling skin gland secretion in two anurans Rana pipiens and Xenopus laevis. Comp. Biochem. Physiol. 30, 857-864.

6. Berger, L., Hyatt, A.D., Speare, R., and Longcore, J.E. 2005. Life cycle stages of the amphibian chytrid Batrachochytrium dendrobatidis. Dis. Aquat. Org. 68, 51-63.

7. Berger, L., Speare, R., Daszak, P., Green, D.E., Cunningham, A.A., Goggin, C.L., Slocombe, R., Ragan, M.A., Hyatt, A.D., McDonald, K.R., et al., 1998.

Chytridiomycosis causes amphibian mortality associated with population declines in the rain forests of Australia and Central America. Proc. Natl. Acad. Sci. USA 95, 9031-9036.

8. Berger, L., Speare, R., Hines, H.B., Marantelli, G., Hyatt, A. D., McDonald, K.R., Skerratt, L.F., Olsen, V., Clarke, J.M., Gillespie, G., Mahony, M., Sheppard, N., Williams, C. and Tyler, M.J. 2004. Effect of season and temperature on mortality in amphibians due to chytridiomycosis. Aust. Vet. J. 82, 434-439. 
9. Blalock, J.E. 2005. The immune system as the sixth sense. J. Intern. Med. 257, 126-

551

552

553

554

555

556

557

558

559

560

561

562

563

564

565

566

567

568

569

570

571 138.

10. Bovbjerg, A.M. 1963. Development of the glands of the dermal plicae in Rana pipiens. J. Morph. 113, 321-243.

11. Bovero, S., Sotgui, G., Angelini, C., Doglio, S., Gazzaniga, E., Cunningham, A.A., and Garner T.W. 2008. Detection of chytridiomycosis caused by Batrachochytrium dendrobatidis in endangered Sardinian newt (Euproctus platycephalus) in southern Sardinia, Italy. J. Wildl. Dis. 44, 712-715.

12. Bradley, G.A., Rosen, P.C., Sredl, M.J., Jones, T.R. and Longcore, J.E. 2002. Chytridiomycosis in native Arizona frogs. J. Wildl. Dis. 38, 206-212.

13. Brown, G.P. and Shine R. 2014. Immune response varies with rate of dispersal in invasive cane toads (Rhinella marina). PLoS One 9(6): e99734.

14. Brunner, J.L., Storfer, A., Gray, M.J., Hoverman, J.T. 2015. Ranavirus ecology and evolution: From epidemiology to extinction. In: Ranaviruses: Lethal pathogens of ectothermic vertebrates. (M.J. Gray and V.G. Chinchar, editors). pp. 71-104. Secaucus, NJ: Springer.

15. Bustamante, H.M., Livo, L.J. and Carey, C. 2010. Effects of temperature and hydric environment on survival of the Panamanian Golden Frog infected with a pathogenic chytrid fungus. Integr. Zool. 5, 143-153.

16. Chambers, D.L., Wojdak, J.M., Du, P., and L.K. Belden. 2013. Pond acidification may explain differences in corticosterone among salamander populations. Physiological and Biochemical Zoology 86, 224-232. 
572 17. Chatfield, M.W.H., Moler, P., and Richards-Zawacki, C.L. 2012. The amphibian

573

574

575

576

577

578

579

580

581

582

583

584

585

586

587

588

589

590

591

592

chytrid fungus, Batrachochytrium dendrobatidis, in fully aquatic salamanders from Southeastern North America. PLoS One 7(9):e44821.

18. Cohen, N. 1966. Tissue transplantation immunity in the adult newt, Diemictylus viridescens $\mathrm{III}$. The effects of $\mathrm{X}$-irradiation and temperature on the allograft reaction. J. Exp. Zool. 163, 231-240.

19. Cohen, N. and Kinney, K.S. 2007. Exploring the phylogenetic history of neuralimmune system interactions: An update. In Psychoneuroimmunology, Fourth Edition, Volume I (ed. R. Ader), pp. 1-38. Burlington, MA: Elsevier Academic Press.

20. Cohen, N., DiMarzo, S., Rollins-Smith, L., Barlow, E., and Vanderschmidt-Parsons, S. 1985. The ontogeny of allo-tolerance and self-tolerance in larval Xenopus laevis. In: Balls M., Bownes M., eds. Metamorphosis. Oxford: Oxford University Press. pp. $388-419$.

21. Collins J.P., 2010. Amphibian decline and extinction: what we know and what we need to learn. Dis. Aquat. Organ. 92, 93-99.

22. Cone, R.E. and Marchalonis, J.J. (1972). Cellular and humoral aspects of the influence of environmental temperature on the immune response of poikilothermic vertebrates. J. Immunol. 108, 952-957.

23. Crespi, E. J. and Denver, R.J. 2005. Roles of stress hormones in food intake regulation in anuran amphibians throughout the life cycle. Comp. Biochem. Physiol. A Mol. Integr. Physiol. 141, 381-390. 
24. Crespi, E.J. and Warne, R.W. 2013. Environmental conditions experienced during the tadpole stage alter post-metamorphic glucocorticoid response to stress in an amphibian. Integr. Comp. Biol. 53, 989-1001.

25. Crespi, E.J., Rissler, L.J., Mattheus, N.M., Engbrecht, K., Duncan, S.I., Seaborn, T., 597 Hall, E.M., Peterson, J.D., and Brunner, J.L. 2015. Geophysiology of wood frogs: Landscape patterns of prevalence of disease and circulating hormone concentrations 599 across the Eastern range. Integr. Comp. Biol. 55, 602-617.

600

601

602

27. de Assis, V.R., Titon, S.D.M., Barsotti, A.M.G., Titon, B. Jr., and Gomes, F.R. 2015.

603

604

605

606

607

608

609

610

611

612

Effects of acute restraint stress, prolonged captivity stress, and transdermal corticosterone application on immunocompetence and plasma levels of corticosterone on the Cururu toad (Rhinella icterica). PLoS One 10 (4), e0121005.

28. De Jusús Andino, F., Chen, G., Li, A., Grayfer, L, and Robert, J. 2012. Susceptibility of Xenopus laevis tadpoles to infection by the ranavirus Frog-Virus 3 correlates with a reduced and delayed innate immune response in comparison with adult frogs. Virology 432, 435-443.

29. Denver, R.J. 1998. Hormonal correlates of environmentally induced metamorphosis in the Western spadefoot toad, Scaphiopus hammondii. Gen. Comp. Endocrinol. 110, $326-336$.

30. Denver, R.J. 2009. Structural and functional evolution of vertebrate neuroendocrine stress systems. Ann. N.Y. Acad. Sci. 1163, 1-16. 
31. Denver, R.J. 2013. Neuroendocrinology of amphibian metamorphosis. Curr. Top. Dev. Biol. 103, 195-227.

32. DiMarzo, S.J. (1980). Ontogeny of alloreactivity in the toad, Xenopus laevis. Ph.D. Thesis. University of Rochester. Rochester, New York.

33. Dores, R.M. and Lecaude S. 2005. Trends in the evolution of proopiomelanocortin gene. Gen. Comp. Endocrinol. 142, 193-205.

34. Drew, A., Allen, E.J., and Allen, L.J.S. 2006. Analysis of climatic and geographic factors affecting the presence of chytridiomycosis in Australia. Dis. Aquat. Organ. 68, 245-250.

35. Du Pasquier, L. and Weiss, N. 1973. The thymus during the ontogeny of the toad Xenopus laevis: growth, membrane-bound immunoglobulins and mixed lymphocyte reaction. Eur. J. Immunol. 3, 773-777.

36. Dunn, A.J. 2006. Effects of cytokines and infections on brain neurochemistry. Clin. Neurosci. Res. 6, 52-68.

37. Echaubard, P., Leduc, J., Pauli, B., Chinchar, V.G., Robert, J., and Lesbarrères, D. 2014. Environmental dependency of amphibian-ranavirus genotypic interactions: evolutionary perspectives on infectious diseases. Evol. Appl. 7, 723-733.

38. Echaubard, P., Little, K., Pauli, B., and Lesbarrères, D. 2010. Context-dependent effects of ranaviral infection on northern leopard frog life history traits. PLoS One, 5(10): e12723.

39. Falso, P.G., Noble, C.A., Diaz, J.M., and Hayes, T.B. 2015. The effect of long-term corticosterone treatment on blood cell differentials and function in laboratory and wild-caught amphibian models. Gen. Comp. Endocrinol 212, 73-83. 
40. Felten, D.L., Felten, S.Y., Bellinger, D.L., Carlson, S.L., Ackerman, K.D., Madden, K.S., Olschowki, J.A., and Livnat, S. 1987. Noradrenergic sympathetic neural interactions with the immune system: structure and function. Immunol Rev 100, 225260.

41. Feuilloley, M., Stolz, M.B., Delarue, C., Fuchère, J.L., and Vaudry H. 1990. Structure-activity relationships of monomeric and dimeric synthetic ACTH fragments in perifused frog adrenal slices. J. Steroid Biochem. 35, 583-592.

42. Fisher, M.C., Henk, D.A., Briggs, C.J., Grownstein, J.S., Madoff, L.C., McCraw, S. L., and Gurr, S.J. 2012. Emerging fungal threats to animal, plant and ecosystem health. Nature 484, 186-194.

43. Gabor, C.R., Fisher, M.C. and Bosch, J. 2013. A non-invasive stress assay shows that tadpole populations infected with Batrachochytrium dendrobatidis have elevated corticosterone levels. PLoS One, 8(2): e56054.

44. Gabor, C.R., Fisher, M.C., and Bosch, J. 2015. Elevated corticosterone levels and changes in amphibian behavior are associated with Batrachochytrium dendrobatidis $(B d)$ infection and $B d$ lineage. PLoS One 10(4): e0122685.

45. Gantress, J., Maniero, G.D., Cohen, N., and Robert J. 2003. Development and characterization of a model system to study amphibian immune responses to iridoviruses. Virology 311, 254-262.

46. Garner, T.W.J., Walker, S., Bosch J., Leech, S., Rowcliffe, J.M. Cunningham, A.A., and Fisher, M.C. 2009. Life history tradeoffs influence mortality associated with the amphibian pathogen Batrachochytrium dendrobatidis. Oikos 118, 
47. Garrido, E., Gomariz, R.P., Leceta, J., and Zapata, A. 1987. Effects of dexamethasone on the lymphoid organs of Rana perezi. Dev. Comp. Immunol. 11, 375-384.

48. Glennemeier, K.A. and Denver, R.J. 2002a. Role for corticoids in mediation the response of Rana pipiens tadpoles to intraspecific competition. J. Exp. Zool. 292, 3240.

49. Glennemeier, K.A. and Denver, R.J. 2002b. Developmental changes in interrenal responsiveness in anuran amphibians. Integ. Comp. Biol. 42, 565-573.

50. Gosner, K.L. 1960. A simplified table for staging anuran embryos and larvae with notes on identification. Herpetologica 16, 183-190.

51. Graham, S., Kelehear, C., Brown, G.P., and Shine, R. 2012. Corticosterone-immune interactions during captive stress in invading Australian cane toads (Rhinella marina). Horm. Behav. 62, 146-153.

52. Gramling C. 2015. Arctic impact. Science 347, 818-821.

53. Gray, M.J. and Chinchar, V.G., Eds. 2015. Ranaviruses: Lethal Pathogens of Ectothermic Vertebrates. Springer. Open Access eBook. [http://www.springer.com/us/book/9783319137544]

54. Gray, M.J., Miller, D.L., and Hoverman, J.T. 2009. Ecology and pathology of amphibian ranaviruses. Dis. Aquat. Organ. 87, 243-266.

55. Gray, M.J., Miller, D.L., Schmutzer, A.C., and Baldwin, C.A.2007. Frog virus 3 prevalence in tadpole populations inhabiting cattle-access and non-access wetlands in Tennessee, USA. Dis. Aquat. Organ. 77, 97-103. 
56. Grayfer, L., and Robert J. 2015. Distinct functional roles of amphibian (Xenopus laevis) colony-stimulating factor-1-and iterleukin-34-derived macrophages. J. Leukoc. Biol. 98, 641-649.

57. Grayfer, L., De Jusús Andino, F., Chen, G., Chinchar, G.V. and Robert, J. 2012. Immune evasion strategies of ranaviruses and innate immune responses to these emerging pathogens. Viruses 4, 1075-1092.

58. Greer, A.L., Berrill, M., and Wilson, P.J. 2005. Five amphibian mortality events associated with ranavirus infection in south central Ontario, Canada. Dis. Aquat Organ. 67, 9-14.

59. Harri, M.N.E. 1981. Hyperglycaemia and hyperlactacidemia as stress indicators in the frog (Rana temporaria). Comp. Biochem. Physiol. C 69, 371-374.

60. Harvey, L.A., Propper, C. R., Woodley, S.K., and Moore, M.C. 1997. Reproductive endocrinology of the explosively breeding desert spadefoot toad, Scaphiopus couchii. Gen. Comp. Endocrinol. 105, 102-113.

61. Heady, J.E. and Kollros, J.J. 1964. Hormonal modification of the development of plical skin glands. Gen. Comp. Endocrinol. 4, 124-131.

62. Hillman, S., Withers, P., and Kimmel, P. 1998. Plasma catecholamines with hemorrhage in the bullfrog, Rana catesbeiana. J. Exp. Zool. 280, 174-181.

63. Holden, W.M., Reinert, L.K., Hanlon, S.M., Parris, M.J., and Rollins-Smith, L.A. 2015. Development of antimicrobial peptide defenses of southern leopard frogs, Rana sphenocephala, against the pathogenic chytrid fungus, Batrachochytrium dendrobatidis. Dev. Comp. Immunol. 48, 65-75. 
64. Holmes, C. and Balls, M. 1978. In vitro studies on the control of myoepithelial cell contractions in the granular glands of Xenopus laevis skin. Gen. Comp. Endocrinol. 36, 255-263.

65. Hoverman, J.T., Gray, M.J., Haislip, N.A., and Miller D.L. 2011. Phylogeny, life history, and ecology contribute to differences in amphibian susceptibility to ranaviruses. EcoHealth 8, 301-319.

66. Hoverman, J.T., Gray, M.J., Miller, D.L., and Haislip, N.A. 2012. Widespread occurrence of ranavirus in pond-breeding amphibian populations. Ecohealth 9, 36-48.

67. Jozkowicz, A. and Plytycz, B. 1998. Temperature but not season affects the transplantation immunity of anuran amphibians. J. Exp. Zool. 281, 58-64.

68. Kaiser, K., Devito, J., Jones, C.G., Marentes, A., Perez, R., Umeh, L., Weickum, R.M., McGovern, K.E., Wilson, E.H., and Saltzman W. 2015. Reproductive and immune effects of chronic corticosterone treatment in male White's treefrogs, Litoria caerulea. Conserv. Physiol. 3, doi:10.1093/conphys/cov022.

69. Katzenback, B.A., Holden, H.A., Falardeau, J., Childers, C., Hadj-Moussa, H., Avis, T.J., and Storey, K.B. 2014. Regulation of the Rana sylvatica brevinin-1SY antimicrobial peptide during development and in dorsal and ventral skin in response to freezing, anoxia and dehydration. J. Exp. Biol. 217, 1392-1401.

70. Kindermann, C., Narayan, E.J., and Hero, J-M. 2012. Urinary corticosterone metabolites and chytridiomycosis disease prevalence in a free-living population of male Stony Creek frogs (Litoria wilcoxii). Comp. Biochem. Physiol. A Mol. Integr. Physiol. 162, 171-176. 
71. Kinney, K.S. and Cohen, N. 2005. Increased splenocyte mitogenesis following sympathetic denervation in Xenopus laevis. Dev. Comp. Immunol. 29, 287-293.

72. Kinney, K.S. and Cohen, N. 2009. Neural-immune system interactions in Xenopus. In: The frog Xenopus as a Model to Study Evolutionary, Developmental, and Biomedical Immunology: Ed. J. Robert. Front. Biosci. 14, 112-129.

73. Kinney, K.S., Cohen, N. and Felten, S.Y. 1994. Noradrenergic and peptidergic innervation of the amphibian spleen: Comparative studies. Dev. Comp. Immunol. 18, $511-521$.

74. Kloas, W. and Hanke, W. 1990. Neurohypophysial hormones and steroidogenesis in the interrenals of Xenopus laevis. Gen. Comp. Endocrinol. 80, 321-330.

75. König, E., Rininda-Emonds, O.R.P. and Shaw, C. 2015. The diversity and evolution of anuran skin peptides. Peptides 63, 96-117.

76. Kriger, K.M. and Hero, J-M. 2007. Large-scale seasonal variation in the prevalence and severity of chytridiomycosis. J. .Zool. 271, 352-359.

77. Leboulenger, F., Lihrmann, I., Netchitailo, P., Delarue, C., Perroteau, I., Ling, N, and Vaudry, H. 1986. In vitro study of frog (Rana ridibunda Pallas) interrenal function by use of a simplified perifusion system. VIII. Structure-activity relationship of synthetic ACTH fragments and gamma MSH. Gen. Comp. Endocrinol. 61, 187-196.

78. Lin, H.H. and Rowlands, D.T. Jr 1973. Thermal regulation of the immune response in South American toads (Bufo marinus). Immunology 24, 129-133.

79. Longcore, J.E., Pessier, A.P., Nichols, D.K., 1999. Batrachochytrium dendrobatidis gen. et sp. nov., a chytrid pathogenic to amphibians. Mycologia 91, 219-227. 
80. Madden, KS and Felten, D L. 1995. Experimental basis for neural-immune interactions. Physiol. Rev. 75, 77-106.

81. Maier, S.F. 2003. Bi-directional immune-brain communication: Implications for 750 understanding stress, pain, and cognition. Brain Behav. Immun. 17, 69-85.

82. Martel, A., Blooi, M., Adriaensen, C., Van Rooij, P., Beukema, W., Fisher, M.C., Farrer, R.A., Schmidt, B.R., Tobler, U., Goka, K., Lips, K.R., Muletz, C., Zamudio, 753 K.R., Bosch, J., Lötters, S., Wombwell, E., Garner, T.W.J., Cunningham. A.A., Spitzen-van der Sluijs, A., Salvidio, S., Ducatelle, R., Nishikawa, K., Nguyen, T.T., Kolby, J.E., Van Bocxlaer, I., Bossuyt, F., and Pasmans, F. 2014. Recent introduction of a chytrid fungus endangers Western Palearctic salamanders. Science 346, 630-631.

83. Martel, A., Spitzen-van derSluijs, A., Blooi, M., Bert, W., Ducatelle, R., Fisher, M.C., Woeltjes, A., Bosman, W., Chiers, K., Bossuyt, F., and Pasmans, F. 2013. Batrachochytrium salamandrivorans sp. nov. causes lethal chytridiomycosis in amphibians. Proc. Natl. Acad. Sci. USA 110, 15325-15329.

84. MbangKollo, D., and deRoos, R. 1983. Comparative effects of epinephrine, norepinephrine, and a gentle handling stress on plasma lactate, glucose, and hematocrit levels in the American bullfrog (Rana catesbeiana). Gen. Comp. Endocrinol. 49, 167-175.

85. McDonald, K.R., Mendez, D., Muller, R., Freeman, A.B., and Speare, R. 2005. Decline in the prevalence of chytridiomycosis in upland frog populations in North Queensland, Australia. Pacific Conserv. Biol. 11, 114-120. 
86. Middlemis Maher, J., Wemer, E.E., and Denver, R.J. 2013. Stress hormones mediate predator-induced phenotypic plasticity in amphibian tadpoles. Proc. R. Soc. B 280, 20123075.

87. Miller, D., Gray, M., and Storfer, A. 2011. Ecopathology of ranaviruses infecting amphibians. Viruses 3, 2351-2373.

88. Morales, H.D., Abramowitz, L., Gertz, J., Sowa, J, Vogel, A and Robert J.2010. Innate immune responses and permissiveness to ranavirus infection of peritoneal leukocytes in the frog Xenopus laevis. J. Virol. 84, 4912-4922.

89. Muletz, C., Caruso, N.M., Fleischer, R.C., McDiarmid, R.W., and Lips, K.R. 2014. Unexpected rarity of the pathogen Batrachochytrium dendrobatidis in Appalachian Plethodon salamanders 1957-2011. PLoS One 9(8):e103728.

90. Narayan, E. and Hero J-M. 2011. Urinary corticosterone responses and haematological stress indicators in the endangered Fijian ground frog (Platymantis vitiana) during transportation and captivity. Aust. J. Zool. 59, 79-85

91. Olson, D.H., Aanensen, D.M., Ronnenberg, K.L., Powell, C.I., Walker, S.F., Bielby, J., Garner, T.W.J., Weaver, G., The Bd Mapping Group and Fisher, M.C. 2013. Mapping the global emergence of Batrachochytrium dendrobatidis, the amphibian chytrid fungus. PLoS One 8, e56802.

92. Orchinik, M., Licht, P., and Crews, D. 1988. Plasma steroid concentrations change in response to sexual behavior in Bufo marinus. Horm. Behav. 22, 338-350.

93. Pachauri, R.K., Allen, M.R., Barros, V.R., Broome, J., Cramer, W. , Christ, R., Church, J.A. , Clarke, L., Dahe, Q. , Dasgupta, P. , Dubash, N.K. , Edenhofer, O. , Elgizouli, I. , Field, C.B. , Forster, P. , Friedlingstein, P. , Fuglestvedt, J. , Gomez- 
Echeverri, L. , Hallegatte, S. , Hegerl, G. , Howden, M. , Jiang, K. , Jimenez

Cisneroz, B. , Kattsov, V. , Lee, H. , Mach, K.J. , Marotzke, J. , Mastrandrea, M.D. , Meyer, L. , Minx, J. , Mulugetta, Y. , O'Brien, K. , Oppenheimer, M. , Pereira, J.J. , Pichs-Madruga, R. , Plattner, G.K. , Pörtner, H.O. , Power, S.B. , Preston, B. , Ravindranath, N.H. , Reisinger, A. , Riahi, K. , Rusticucci, M. , Scholes, R. , Seyboth, K. , Sokona, Y., Stavins, R. , Stocker, T.F. , Tschakert, P. , van Vuuren, D. and van Ypserle, J.P. (2014). Climate Change 2014: Synthesis Report. Contribution of Working Groups I, II and III to the Fifth Assessment Report of the Intergovernmental Panel on Climate Change / R. Pachauri and L. Meyer (editors), Geneva, Switzerland, IPCC, 151 p., ISBN: 978-92-9169-143-2.

94. Parris, M.J. and Cornelius, T.O. 2004. Fungal pathogen causes competitive and developmental stress in larval amphibian communities. Ecology 85, 3385-3395.

95. Pask, J.D., Cary, T.L., Rollins-Smith, L.A., 2013. Skin peptides protect juvenile leopard frogs (Rana pipiens) against chytridiomycosis. J. Exp. Biol. 216, 2908-2916.

96. Pask, J.D., Woodhams, D.C., Rollins-Smith, L.A., 2012. The ebb and flow of antimicrobial skin peptides defends northern leopard frogs (Rana pipiens) against chytridiomycosis. Glob. Change Biol. 18, 1231-1238.

97. Pasmans, F., Van Rooij, P., Blooi, M., Tessa, G., Bogaerts, S., Sotgiu, G., Garner, T.W., Fisher, M.C., Schmidt, B.R., Woeltjes, T., Beukema, W., Bovero, S., Adriaensen, C., Oneto, F., Ottonello, D., Martel, A., and Salvidio, S. 2013. Resistance to chytridiomycosis in European plethodontid salamanders of the genus Speleomantes. PLoS One 8(5):e63639. 
98. Perry, S.F. and Capaldo, A. 2011. The autonomic nervous system and chromaffin tissue: Neuroendocrine regulation of catecholamine secretion in non-mammalian vertebrates. Auton. Neurosci. 165, 54-66.

99. Pessier, A.P., Nichols, D.K., Longcore, J.E., Fuller, M.S. 1999. Cutaneous chytridiomycosis in poison dart frogs (Dendrobates spp.) and White's tree frogs (Litoria caerulea). J. Vet. Diagn. Invest. 11, 194-199.

100. Peterson, J.D., Steffen, J.E., Reinert, L.K., Cobine, P.A., Appel, A., Rollins-Smith, L., and Mendonca, M.T. 2013. Host stress response is important for the pathogenesis of the deadly amphibian disease, chytridiomycosis, in Litoria caerulea. PLoS One 8(4): e62146.

101. Piotrowski, J.S., Annis, L.S. and Longcore, J.E. 2004. Physiology of Batrachochytrium dendrobatidis, a chytrid pathogen of amphibians. Mycologia 96, 915.

102. Plytycz B., Kusina, E., and Józkowicz, A. 1993. Effects of hydrocortisone on lymphoid organs of Rana temporaria. Folia Histochem. Cytobiol. 31, 129-132.

103. Pounds, J.A., Bustamante, M.R., Coloma, L.A., Consuegra, J.A., Fogden, M.P., Foster, P.N., LaMarca, E., Masters, K.L., Merino-Viteri, A., Puschendorf, R., Ron, S. R., Sánchez-Azofeifa, G.A., Still, C.J., \& Young, B.E. 2006. Widespread amphibian extinctions from epidemic disease driven by global warming. Nature 439, 161-167.

104. Raffel, T. R., Romansic, J.M., Halstead, N.T., McMahon, T.A., Venesky, M.D. and Rohr, J.R. 2013. Disease and thermal acclimation in a more variable and unpredictable climate. Nature Climate Change 3, 146-151. 
105. Raffel, T.R., Halstead, N.T., McMahon, T.A., Davis, A.K., and Rohr, J.R. 2015. Temperature variability and moisture synergistically interact to exacerbate and epizootic disease. Proc. Biol. Sci. 282(1801):20142039.

106. Ramakrishnan, L., Valdivia, R.H., McKerrow, J.H., and Falkow, S. 1997. Mycobacterium marinum causes both long-term subclinical infection and acute disease in the leopard frog (Rana pipiens). Infect. Immun. 65, 767-773.

107. Ramsey, J.P., Reinert, L.K., Harper, L.K., Woodhams, D.C., Rollins-Smith, L.A., 2010. Immune defenses against Batrachochytrium dendrobatidis, a fungus linked to global amphibian declines, in the South African clawed frog, Xenopus laevis. Infect. Immun. 78, 3981-3992.

108. Reeve, B.C., Crespi, E.J., Whipps, C. M., and Brunner, J.L. 2013. Natural stressors and ranavirus susceptibility in larval wood frogs (Rana sylvatica). EcoHealth 10, 190200.

109. Robert J., Abramowitz, L., Gantress, J., and Morales, H.D. 2007. Xenopus laevis: a possible vector of ranavirus infection. J. Wildl. Dis. 43, 645-652.

110. Robert, J., and Ohta, Y. 2009. Comparative and developmental study of the immune system in Xenopus. Dev. Dynam. 238, 1249-1270.

111. Robert, J., Grayfer, L., Edholm, E.S., Ward, G., and De Jusús Andino, F. 2014. Inflammation-induced reactivation of the ranavirus Frog Virus 3 in asymptomatic Xenopus laevis. PLoS One 9(11):e112904.

112. Rohr, J.R. and Raffel, T.R. 2010. Linking global climate and temperature variability to widespread amphibian declines putatively caused by disease. Proc. Natl. Acad. Sci. USA $107,8269-8274$. 
113. Rojas, S., Richards, K., Jancovich, J.K., and Davidson, E.W. 2005. Influence of temperature on Ranavirus infection in larval salamanders Ambystoma tigrinum. Dis. Aquat. Organ. 63, 95-100.

114. Rollins, L.A. and McKinnell, R.G. 1980. The influence of glucocorticoids on survival and growth of allografted tumors in the anterior eye chamber of leopard frogs. Dev. Comp. Immunol. 4, 283-294.

115. Rollins-Smith, L.A. and Blair, P.J. 1993. The effects of corticosteroid hormones and thyroid hormones on lymphocyte viability and proliferation during development and metamorphosis of Xenopus laevis. Differentiation 54, 155-160.

116. Rollins-Smith, L.A., 1998. Metamorphosis and the amphibian immune system. Immunol. Rev. 166, 221-230.

117. Rollins-Smith, L.A., 2009. The role of amphibian antimicrobial peptides in protection of amphibians from pathogens linked to global amphibian declines. Biochim. Biophys. Acta. 1788, 1593-1599.

118. Rollins-Smith, L.A., Barker, K.S., and Davis, A.T. 1997. Involvement of glucocorticoids in the reorganization of the amphibian immune system at metamorphosis. Dev. Immunol. 5, 145-152.

119. Rollins-Smith, L.A., Conlon, J.M., 2005. Antimicrobial peptide defenses against chytridiomycosis, an emerging infectious disease of amphibian populations. Dev. Comp. Immunol. 29, 589-598.

120. Rollins-Smith, L.A., Parsons, S.C.V. and Cohen, N. 1984. During frog ontogeny, PHA and Con A responsiveness of splenocytes precedes that of thymocytes. Immunology 52, 491-500. 
121. Rollins-Smith, L.A., Parsons, S.C.V., and Cohen, N. 1988. Effects of thyroxinedriven precocious metamorphosis on maturation of adult-type allograft rejection responses in early thyroidectomized frogs. Differentiation 37, 180-185.

122. Rollins-Smith, L.A., Ramsey, J.P., Pask, J.D., Reinert, L.K., and Woodhams, D.C. 2011. Amphibian immune defenses against chytridiomycosis: Impacts of changing environments. Integr. Comp. Biol. 51, 552-562.

123. Rollins-Smith, L.A., Woodhams, D.C., 2012. Amphibian immunity: staying in tune with the environment. In Eco-Immunology (ed. G.E. Demas and R.J Nelson), pp. 92143. Oxford, United Kingdom: Oxford University Press.

124. Savage, A.E., Sredl, M.J., and Zamudio, K.R. 2011. Disease dynamics vary spatially and temporally in a North American amphibian. Biol. Conserv. 144, 1910-1915.

125. Schär, C., Vidale, P.L., Lüthi, D., Frei, C., Häberli, C., Liniger, M.A., and Appenzeller, C. 2004. The role of increasing temperature variability in European summer heatwaves. Nature 427, 332-336.

126. Seki, T., Kikuyama, S., and Yanaihara, N. 1989. Development of Xenopus laevis skin glands producing 5-hydroxytryptamine and caerulein. Cell. Tissue Res. 258, 483-489.

127. Sjoberg, E. and Flock, A. 1976. Innervation of skin glands in the frog. Cell Tiss. Res. $172,81-91$.

128. Skerratt, L.F., Berger, L., Speare, R., Cashins, S., McDonald, K.R., Phillott, A.D., Hines, H.B., and Kenyon, N. 2007. Spread of chytridiomycosis has caused the rapid global decline and extinction of frogs. Ecohealth 4, 125-134.

129. Smith, E.M. 2003. Opioid peptides in immune cells. Adv. Exp. Med. Biol., 52151 68. 
130. Stuart, S.N., Chanson, J.S., Cox, N.A., Young, B.E., Rodrigues, A.S.L., Fischman, D.L., Waller, R.W., 2004. Status and trends of amphibian declines and extinctions worldwide. Science 306, 1783-1786.

131. Thien, T.N., Martel, A., Brutyn, M., Bogaerts, S., Sparreboom, M., Haesebrouck, F., Fisher, M.C., Beukema, W., Van, T.D., Chiers, K. and Pasmans. F. 2013. A survey for Batrachochytrium dendrobatidis in endangered and highly susceptible Vietnamese salamanders (Tylototriton spp.). J. Zoo. Wildl. Med. 44, 627-633.

132. Tufts, B.L., Mense, D.C., and Randall, D.J. 1987. The effects of forced activity on circulating catecholamines and $\mathrm{pH}$ and water content of erythrocytes in the toad. J. Exp. Biol. 128, 411-418.

133. Venesky, M.D., Parris, M.J., and Storfer, A. 2009. Impacts of Batrachochytrium dendrobatidis infection on tadpole foraging performance. EcoHealth 6, 565-575.

134. Venesky, M.D., Wilcoxen, T.E., Rensel, M.A., Rollins-Smith, L., Kerby, J.L., and Parris, M.J. 2012. Dietary protein restriction impairs growth, immunity, and disease resistance in southern leopard frog (Lithobates sphenocephalus) tadpoles. Oecologia. $169,23-31$.

135. Voyles, J., Johnson, L. R., Briggs, C. J., Cashins, S. D., Alford, R. A., Berger, L., Skerratt, L. F., Speare, R. and Rosenblum E. B. 2012a. Temperature alters reproductive life history patterns in Batrachochytrium dendrobatidis, a lethal pathogen associated with the global loss of amphibians. Ecol. Evol. 2, 2241-2249.

136. Voyles, J., Vredenburg, V.G., Tunstall, T.S., Parker, J.M., Briggs, C.J., and Rosenblum, E.B. 2012b. Pathophysiology in mountain yellow-legged frogs (Rana muscosa) during a chytridiomycosis outbreak. PLoS One 7(4): e35374. 
137. Voyles, J., Young. S., Berger, L., Campbell, C., Voyles, W.F., Dinudom, A., Cook, D., Webb, R., Alford, R.A., Skerratt, L.F., and Speare, R. 2009. Pathogenesis of chytridiomycosis, a cause of catastrophic amphibian declines. Science 26, 582-585.

138. Warne, R.W. and Crespi, E.J. 2015. Larval growth rate and sex determine resource allocation and stress responsiveness across life states in juvenile frogs. J. Exp. Zool. 323A, 191-201.

139. Warne, R.W., Crespi, E.J., and Brunner, J.L. 2011. Escape from the pond: stress and developmental responses to ranavirus infection in wood frog tadpoles. Funct. Ecol. $25,139-146$.

140. Warne, R.W., Kardon, A., and Crespi, E.J. 2013. Physiological, behavioral and maternal factors that contribute to size variation in larval amphibian populations. PLoS One 8(10), e76364.

141. Webster, J.I., and Sternberg, E.M. 2004. Role of the hypothalamic-pituitary-adrenal axis, glucocorticoids and glucocorticoid receptors in toxic sequelae of exposure to bacterial and viral products. J. Endocrinol. 181, 207-221.

142. Withers, P.C., Hillman, S.S. and Kimmel, P.B. 1988. Effects of activity, hemorrhage, and dehydration on plasma catecholamine levels in the marine toad (Bufo marinus). Gen. Comp. Endocrinol. 72, 63-71.

143. Woodhams, D.C. and Alford, R.A. 2005. Ecology of chytridiomycosis in rainforest stream frog assemblages of tropical Queensland. Conserv. Biol. 19, 1449-1459.

144. Woodhams, D.C., Alford, R.A., Briggs, C.J., Johnson, M., and Rollins-Smith, L.A. 2008. Life-history trade-offs influence disease in changing climates: strategies of an amphibian pathogen. Ecology 89, 1627-1639. 
957 Figure Legend

958

959

960

961

962 and steroidogenic tissues in the interrenal glands respond by release of epinephrine and

963 norepinephrine or corticosterone and aldosterone, respectively. Extreme stress may result in

964 diminished AMPs or lymphocyte loss and impaired immune defenses. 
Stress !!

Desiccation

Extreme temps

Frog brain

Predator

hypothalamus

Disease

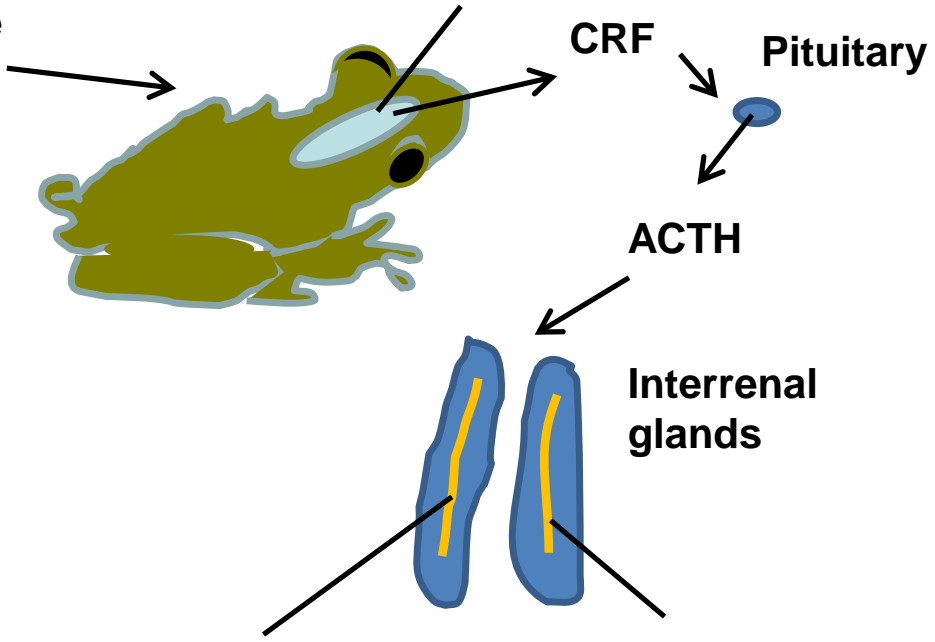

Chromaffin tissue

Steroidogenic tissues

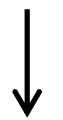

Epinephrine

Norepinephrine

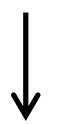

Acute danger

response.

Release of

AMPs

$$
\downarrow
$$

Extreme stress may

result in fewer AMPs

or temporary

depletion of skin

peptides.

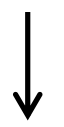

Corticosteroid hormones (corticosterone \& aldosterone)<smiles>C=[V]</smiles>

Energy mobilization. Rebalance of water \& essential ions.

$$
\downarrow
$$

Extreme stress may result in loss of lymphocytes, mobilization of other leukocytes.

Fig. 1. Schematic diagram of stress and HPI axis in amphibians. Stress activates the hypothalamus to release corticotropin-releasing factor (CRF). CRF acts on the pituitary to induce release of corticotropin (homologous to adrenocorticotropic hormone, ACTH). Chromaffin tissue and steroidogenic tissues in the interrenal glands respond by release of epinephrine and norepinephrine or corticosterone and aldosterone, respectively. Extreme stress may result in diminished AMPs or lymphocyte loss and impaired immune defenses. 